\title{
Carbon dioxide-expanded ethanol-assisted synthesis of carbon-based metal composites and their catalytic and electrochemical performance in lithium-ion batteries
}

\author{
Lingyan Wang a, Linhai Zhuo b,*, Fengyu Zhao c,\# \\ a School of Chemistry and Chemical Engineering, Qufu Normal University, Qufu 273165, Shandong, China \\ ${ }^{\mathrm{b}}$ College of Chemistry and Chemical Engineering, Taishan University, Tai'an 271021, Shandong, China \\ 'State Key Laboratory of Electroanalytical Chemistry, and Laboratory of Green Chemistry and Process, Changchun Institute of Applied Chemistry, Chinese \\ Academy of Sciences, Changchun 130022, Jilin, China
}

\section{A R T I C L E I N F O}

\section{Article history:}

Received 5 November 2015

Accepted 2 December 2015

Published 5 February 2016

\section{Keywords:}

$\mathrm{CO}_{2}$-expanded ethanol

Carbon

Metal oxide

Catalysis

Electrochemistry

\begin{abstract}
A B S T R A C T
Highly dispersed metals, metal oxides and their composites on substrates have received considerable interest in catalysis and lithium-ion batteries, because of their superior properties compared with their single-component counterparts. In this review, we introduce the properties of supercritical carbon dioxide $\left(\mathrm{scCO}_{2}\right)$ expanded ethanol, such as low viscosity, near-zero surface tension and high diffusivity. We discuss the deposition procedure and formation mechanism of carbon-based composites in $\mathrm{scCO}_{2}$-expanded ethanol. This method has been used to fabricate several carbon-based composites, such as metal and metal oxide composites deposited on zero-dimensional colloidal carbon, one-dimensional carbon nanotubes, two-dimensional graphene, and three-dimensional hierarchical porous carbon. These materials and their performance as anodic materials for lithium-ion batteries will also be reviewed.
\end{abstract}

(C) 2016, Dalian Institute of Chemical Physics, Chinese Academy of Sciences. Published by Elsevier B.V. All rights reserved.

\section{Introduction}

Functional composites have attracted much recent interest in various areas. This is because they often behave differently from bulk materials, and exhibit improved properties compared with their single-component counterparts. For example, precious metal seeds encapsulated by metal and metal oxides, such as Pt@CoO [1], Au@ZrO2 [2], and Pd@Au [3], exhibit higher stability, activity, and selectivity than their bare metal nanoparticles. This is because of the local effect and synergistic interactions between the core metal particles and shell metal oxides. Various carbon-based composites, such as $\mathrm{SnO}_{2}$ /graphene [4], $\mathrm{Fe}_{3} \mathrm{O}_{4} / \mathrm{C}$ [5], and $\mathrm{Co}_{3} \mathrm{O}_{4}$ /graphene [6], have been investigated for use in lithium-ion batteries (LIBs), in which they exhibit better electrochemical performance than their single metal oxide components. Carbon-based composites have been much studied as catalysts or catalyst supports, and favorable catalytic performance have been reported [7-10]. Bao's group [7] reported that reduced graphene oxide could be used as a catalyst for the hydrogenation of nitrobenzene at

\footnotetext{
* Corresponding author. Tel: +86-538-6715156; Fax: +86-538-6715599; E-mail: zhuoling77@163.com

\# Corresponding author. Tel: +86-431-85262410; Fax: +86-431-85262410; E-mail: zhaofy@ciac.ac.cn

This work was supported by the international cooperation project (21311140166) of the National Natural Science Foundation of China and Japan Science Promotion Society (NNSFC-JSPS), NNSFC (21273222), Shandong Province Science and Technology Program (2014GGX102020), Higher Educational Science and Technology Program (J14LC08), the Doctoral Scientific Research Start-Up Foundation of Qufu Normal University, and the Science and Technology Program of Qufu Normal University (xkj201508).
}

DOI: 10.1016/S1872-2067(15)61024-5 | http://www.sciencedirect.com/science/journal/18722067 | Chin. J. Catal., Vol. 37, No. 2, February 2016 
room temperature, and high catalytic activity and stability were obtained. Wang's group [8] prepared ultrafine Pd nanoparticle monolayers on graphene oxide, which exhibited high electrocatalytic ability in the oxidation of formic acid and ethanol. Liu' group [9] deposited Pt nanoparticles on multi-walled carbon nanotubes, which exhibited a turn-over frequency (TOF) of $69900 \mathrm{~h}^{-1}$ in the hydrogenation of nitrobenzene.

Synthesizing these composites usually requires uniformly coating or dispersing metal and metal oxides onto the core particles. Cao' group [11] reported that Ni-graphene nanocomposites with uniformly distributed nickel particles significantly lowered the decomposition temperature of ammonium perchlorate (AP). This was because of the reduced activation energy of the decomposition of AP, which enhanced the rate of decomposition of deprotonated $\mathrm{HClO}_{4}$ gas. Balaya [12] reported that reducing the size of nanocrystals, which increases their surface-to-volume ratio, could reduce the scale of transport lengths for mass and charge transport. Nanoscale effects promoted the thermodynamic properties, because of excess surface contributions enhancing the cell voltage in LIBs. Controlling the loading of active materials is important, because it significantly influences the performance of the resulting composite. For example, Lee and co-workers [13] reported that $\mathrm{Fe}_{3} \mathrm{O}_{4}$ nanocrystals confined in mesocellular carbon foam (MSU-F-C) exhibited excellent rate performance compared with micro- $\mathrm{Fe}_{3} \mathrm{O}_{4}$. The higher $\mathrm{Fe}_{3} \mathrm{O}_{4}$ loading (61\%) decreased the rate performance, which was attributed largely to the lower pore volume.

Several approaches have been reported for impregnating or attaching active metal and metal oxide nanoparticles into the cavities or on the external walls of supports. Incorporating metals or metal precursors and a carbon source for carbon nanotube (CNT) growth is one approach for impregnating metals into the hollow interior of CNTs. However, harsh conditions such as high temperatures or arc evaporation are usually required, and impurities are produced as encapsulated carbon clusters and soot. Capillary drawing of low-melting point metals into CNTs is a simple approach. However, CNTs are not wetted by liquids with surface tensions higher than $0.1-0.2$ $\mathrm{N} / \mathrm{m}$, which excludes most common metal catalysts [14]. The most promising and flexible approach is to deposit metals into the cavities or onto the external walls of CNTs through reactions such as chemical vapor deposition (CVD) or wet chemical processing. The small inner diameter and extremely high aspect ratio of CNTs means these approaches require high temperatures or long reaction time to fill metals into the inner cavities. As a consequence, the filling percentage of the CNTs is often low. Pristine CNT surfaces are rather inert and poorly hydrophilic, so this approach also results in unsatisfactory adhesion, and poor control of the coverage of the metal nanoparticles on the CNT outer walls. Most catalysis application prefers catalyst particles loaded onto the exteriors of CNTs, where they are more accessible to reactant molecules than those on interior surfaces. To obtain specific nucleation of metals on the outer surface with good adhesion and dispersion, CNTs are usually functionalized by chemical treatment with oxidants such as $\mathrm{HNO}_{3}, \mathrm{KMnO}_{4}, \mathrm{HNO}_{3} / \mathrm{H}_{2} \mathrm{SO}_{4}$ and $\mathrm{RuO}_{4}$. This generates $-\mathrm{COOH}$,
$-\mathrm{OH}$ and other functional groups on the external walls of the CNTs. The conventional wet chemical decoration processes usually involve tedious and time-consuming treatments of the CNTs, which generates significant aqueous waste.

An effective and green approach for uniformly dispersing metal and metal oxides or composites nanoparticles on carbon-based matrices has recently been developed. This approach involves assistance by $\mathrm{CO}_{2}$-expanded ethanol, and the carbon-based matrix can be used directly without tedious pretreatment. Several metal oxides have been deposited on the outer surfaces of CNTs, such as $\mathrm{Co}_{3} \mathrm{O}_{4} / \mathrm{CNT}$ [15], $\mathrm{Eu}_{2} \mathrm{O}_{3} / \mathrm{CNT}$ [16], $\mathrm{Al}_{2} \mathrm{O}_{3} / \mathrm{CNT}$ [17], $\mathrm{Fe}_{2} \mathrm{O}_{3} / \mathrm{CNT}$ [18], $\mathrm{ZrO}_{2} / \mathrm{CNT}$ [19], and $\mathrm{La}_{2} \mathrm{O}_{3} / \mathrm{CNT}$ [20], in a solution of supercritical $\mathrm{CO}_{2}$ $\left(\mathrm{scCO}_{2}\right)$-modified ethanol. The coating thickness could be tailored by tuning the ratio of the initial mass of precursors to CNTs. The metal or metal oxides nanocrystals or nanoalloys, and complex metal oxide nanoparticles were dispersed on carbon-based matrices with different dimensions, in $\mathrm{scCO}_{2}$-expanded ethanol without using precipitants. Matrices have included zero-dimensional (OD) carbon colloids (C@Ni, CoO/C, C@Ni\&Co, C@Ni\&Pd [21], Pd/C [22]), one-dimensional (1D) CNTs $\left(\mathrm{Co}_{3} \mathrm{O}_{4} / \mathrm{CNTs}\right.$ [23], $\mathrm{CoFe}_{2} \mathrm{O}_{4} / \mathrm{CNTs}$ [24]), two-dimensional (2D) graphene (NiO@GNS [25], $\mathrm{Fe}_{3} \mathrm{O}_{4} @ \mathrm{GNS}$ [26], $\mathrm{CoFe}_{2} \mathrm{O}_{4} @ G N S$ [27]), and three-dimensional (3D) hierarchical porous carbon $\left(\mathrm{Fe}_{3} \mathrm{O}_{4} / 3 \mathrm{DHPC}\right.$ [28], NiO/3DHPC, $\mathrm{Co}_{3} \mathrm{O}_{4} / 3 \mathrm{DHPC}, \mathrm{NiCo}_{2} \mathrm{O}_{4} / 3 \mathrm{DHPC}$ [29]). These nanocomposites have exhibited good performance in catalytic hydrogenation, or good electrochemical performance in LIBs.

\section{2. $\mathrm{ScCO}_{2}$-expanded ethanol deposition}

$\mathrm{scCO}_{2}$ deposition is a green and sustainable technique for efficiently synthesizing and processing nanomaterials. $\mathrm{scCO}_{2}$ is an attractive alternative to organic solvents, because it is nontoxic, nonflammable, inexpensive, naturally abundant and chemically inert. Its physical properties such as density and solvent power can be tuned via the operating temperature and pressure [28]. Its low viscosity, near-zero surface tension and high diffusivity are favorable for synthesizing ultrafine uniform nanomaterials, and for enhancing reaction rates [30]. $\mathrm{scCO}_{2}$ deposition also has advantages for processing cellular materials, because it can mitigate mass transfer limitations, facilitate the infiltration of precursors into complex geometries, and maintain a porous nanostructure without collapse. $\mathrm{scCO}_{2}$ as a reaction medium could also reduce the solvent strength caused by hydroxyl groups originating from ethanol and water, and thus suppress aggregation of the final particles [20]. Polar organic solvents are usually used as cosolvents to enhance the solvent strength of $\mathrm{scCO}_{2}$, resulting in $\mathrm{scCO}_{2}$-based solutions. For example, metal nitrates (e.g. cobalt, iron, and aluminum nitrates) are insoluble in $\mathrm{scCO}_{2}$, but are soluble in $\mathrm{scCO}_{2}$ /ethanol under the appropriate conditions. These nitrates can decompose into their respective metal oxides at relatively low temperatures in the presence of $\operatorname{scCO}_{2}$ [31].

In the general procedure, a nitrate ethanol solution containing carbon-based supports is loaded into a high-pressure stainless-steel vessel, as the vessel is preheated to a certain 
temperature. $\mathrm{CO}_{2}$ is then introduced until the solution reaches a homogeneous state. The vessel is then heated to the desired temperature $\left(100-200{ }^{\circ} \mathrm{C}\right)$, which depends on the metal nitrate. This causes the metal nitrate to decompose and deposit onto the carbon matrix. Subsequent calcination yields the final metal oxide-carbon nanocomposite.

\section{Procedure and mechanism of deposition in $\mathrm{scCO}_{2}$-expanded ethanol}

The behavior of hydrous inorganic metal nitrates during the deposition of metal composites in $\mathrm{scCO}_{2}$-expanded ethanol at $50-200{ }^{\circ} \mathrm{C}$ has been investigated [31]. This study investigated the phase behavior, deposition mechanism, reaction rate, and effect of the template on deposition. A suitable temperature ensures that reaction of metal precursor occurs in the expanded fluid. A temperature range of $80-100{ }^{\circ} \mathrm{C}$ is suitable for $\mathrm{Fe}\left(\mathrm{NO}_{3}\right)_{3} \cdot 9 \mathrm{H}_{2} \mathrm{O}$ to form a stable homogenous $\mathrm{scCO}_{2}$-expanded ethanol solution of $\mathrm{Fe}\left(\mathrm{NO}_{3}\right)_{3} \cdot 9 \mathrm{H}_{2} \mathrm{O}$. Cobalt, nickel and chromium nitrates are all stable at $150{ }^{\circ} \mathrm{C}$. Their phase behavior demonstrates that hydrous inorganic metal salts have a specific solubility in $\mathrm{scCO}_{2}$-expanded solution. To form a homogeneous fluid, the concentration of most hydrous metal nitrate salts should be $<0.13 \mathrm{~mol} / \mathrm{L}$, depending on the type of metal compound [31].

The deposition of hydrous inorganic metal salts in $\mathrm{scCO}_{2}$-expanded ethanol has been shown in Fig. 1 to proceed through precipitation and decomposition reactions [31]. First, the hydrous inorganic metal salt dissociates in ethanol, forming a solution containing $\mathrm{M}^{2+}, \mathrm{NO}_{3}^{-}$, and $\mathrm{H}_{2} \mathrm{O}$. Introducing $\mathrm{CO}_{2}$ causes $\mathrm{H}_{2} \mathrm{O}$ to react with $\mathrm{CO}_{2}$, generating $\mathrm{CO}_{3}{ }^{2-}$ and $\mathrm{HCO}_{3}{ }^{-}$. Before deposition, free $\mathrm{NO}_{3}{ }^{-}$and $\mathrm{CO}_{3}{ }^{2-}$ interact with $\mathrm{M}^{2+}$, through electronic interaction in the expanded homogeneous fluid. At reaction temperature, dissociated anions (e.g. $\mathrm{NO}_{3}{ }^{-}$and $\mathrm{CO}_{3}{ }^{2-}$ ) and molecules $\left(\mathrm{H}_{2} \mathrm{O}\right)$ coordinate directly to the matrix $\mathrm{M}^{2+}$ by bridging oxygen groups, forming a solid compound. The high strength of the coordinate bonds results in a stable compound, which precipitates from the fluid. Thus, the metal oxide is formed from the decomposition of the solid compound, rather than the simple decomposition of primary precursors as reported before [20]. This coordination-decomposition mechanism suggests that chlorides could also act as precursors, except for some special situations limited to nitrates. This is because $\mathrm{CO}_{3}{ }^{2-}$ resulting from $\mathrm{CO}_{2}$ coordinates strongly with metal ions, while $\mathrm{Cl}^{-}$coordinates more weakly.

\section{Synthesis and performance of carbon-based composites}

\subsection{Zero-dimensional carbon-based composites}

Preparing metal colloid particles with controllable size, shape and composition has received much recent attention, because of their wide application. Supported colloidal metal particles are generally prepared by the adsorption of colloidal nanoparticles, or the grafting of colloids on solid supports by evaporation or electrodeless deposition. These procedures require a complex support modification step, and a surfactant or stabilizer is necessary to stabilize the metal particles. The modifier or stabilizer can hinder the deposition of nanoparticles, and lower their activity because of geometry restrictions. Therefore, surfactants or stabilizers should be removed when preparing supported metal colloid catalysts, but this can then lead to growth of the colloidal particles and/or large amounts of waste. An effective and simple green process is desirable, especially one that does not involve stabilizers.

A simple and green method for removing the stabilizer using $\mathrm{scCO}_{2}$ has been developed. Monodisperse Pd colloidal nanoparticles protected with polyvinylpyrrolidone (PVP) were uniformly coated on carbon colloidal spheres. PVP was removed using the phase-switch function of $\mathrm{scCO}_{2}$, without resulting in particle conglomeration. This process is shown in Fig. 2. $\mathrm{Pd} / \mathrm{C}$ or $\mathrm{Pd} / \mathrm{SiO}_{2}$ prepared in the presence of $\mathrm{CO}_{2}(8.0 \mathrm{MPa})$ exhibited higher activity in the hydrogenation of maleic anhy-

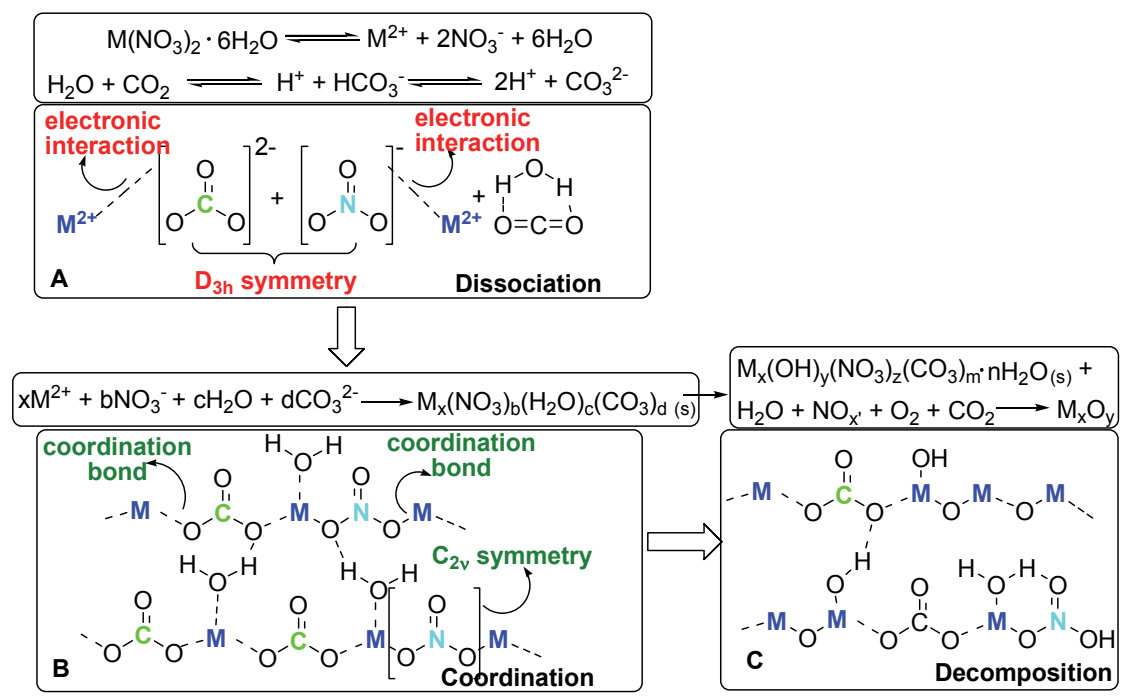

Fig. 1. Proposed deposition mechanism of a hydrous metal salt in $\mathrm{scCO}_{2}$-expanded ethanol. (A) Behavior of dissociated ions and molecules; (B) Coordination of ions and molecules to form a solid compound; (C) Further decomposition of the solid compound [31]. 


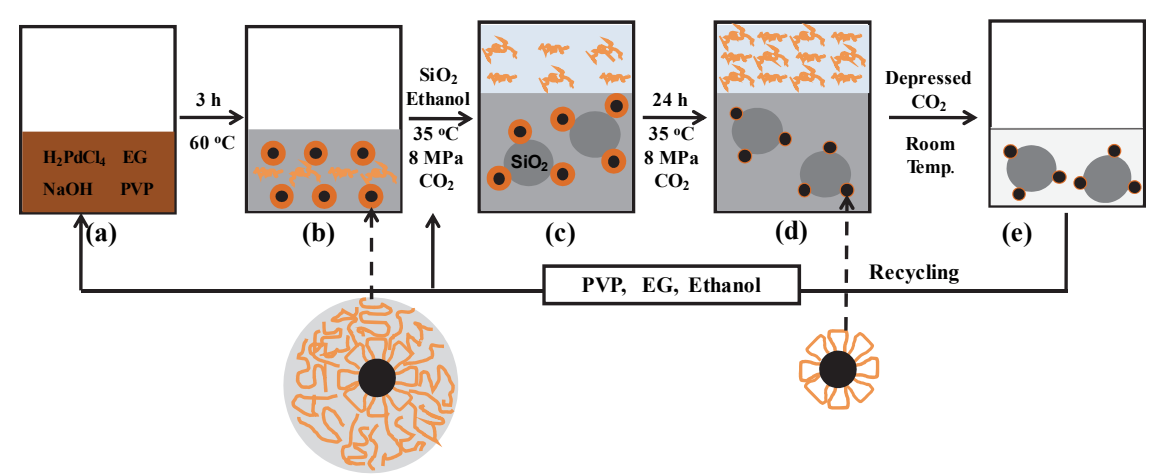

Fig. 2. Process for forming $\mathrm{Pd} / \mathrm{SiO}_{2}$ in $\mathrm{scCO}_{2}$-expanded ethanol. Reproduced from Ref. [22] with permission from the Royal Society of Chemistry.

dride than highly dispersed Pd colloidal particles. The catalyst also exhibited good stability during the reaction, because a PVP monolayer remained on the Pd particle surface. This monolayer suppressed leaching and aggregation of the Pd particles during reaction [22].

Various core-shell particles containing shells of dispersed metal (oxides) nanocrystals or nanoalloys have been prepared, such as C@Ni, CoO/C, C@Ni\&Co and C@Ni\&Pd particles, through the in situ reaction of precursors in $\mathrm{scCO}_{2}$-expanded ethanol without using precipitants [21]. This avoided forming free metal or metal oxide and naked cores, and allowed individual particles to disperse without aggregating. The composition, thickness, uniformity, and structure of the metal and metal oxide shell could be controlled. For example, perfect core-shell $\mathrm{C} @ \mathrm{Ni}$ and supported $\mathrm{CoO} / \mathrm{C}$ particles have been produced. Individual particles were well dispersed over a wide area without aggregation. Each particle contained a uniform coating, as shown in Fig. 3. The dispersed nanocrystals as building blocks of the shell had a narrow size distribution, with a particle size of $<5 \mathrm{~nm}$. Uniform and dispersed $\mathrm{SiO}_{2} @ \mathrm{NiO}$ and $\mathrm{SiO}_{2} @ \mathrm{Fe}_{2} \mathrm{O}_{3}$ core-shell particles were obtained when silica gel was used as a core particle. The shell could be controlled by varying the precursor concentration. C@Ni exhibited high activity in the hydrogenation of nitrobenzene. It gave a conversion of $95 \%$, which was nearly double that of the $\mathrm{Ni} / \mathrm{Al}_{2} \mathrm{O}_{3}$ catalyst [21].
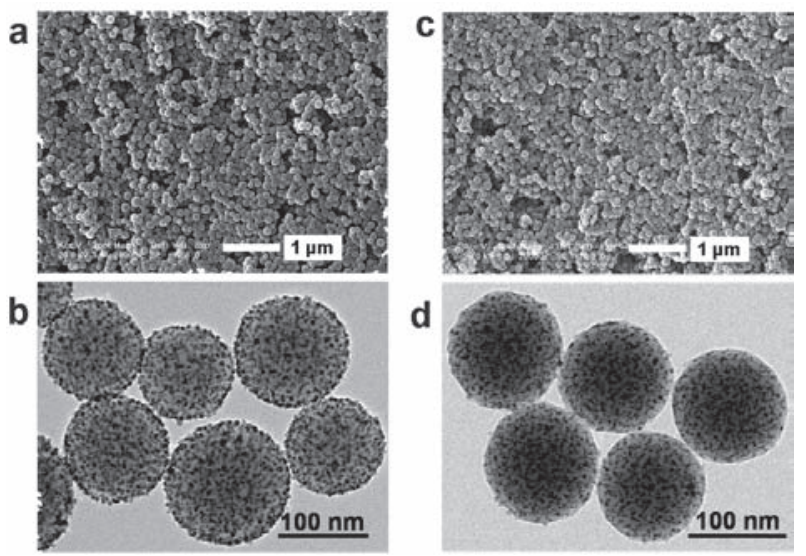

Fig. 3. SEM and TEM images of (a, b) C@Ni and (c, d) supported CoO/C particles. Reproduced from Ref. [21] with permission from the Royal Society of Chemistry.
Similar procedures have yielded core-shell C@Ni\&Co and C@Ni\&Pd, with tunable molar ratios of metals. The shell composition could be controlled by varying the concentration and type of precursor. $\mathrm{scCO}_{2}$-expanded ethanol-assisted deposition is a flexible and straightforward method for precisely coating multi-component shells on particles, while maintaining the individual particle dispersion. Carbon-based composites with dispersed metal nanoalloys or metal colloidal particles are likely to have applications in catalysis, magnetism and electronics.

\subsection{One-dimensional CNT-based composites}

CNTs have received much recent attention because of their mechanical and electronic properties, and widespread potential application. Their small size, high chemical stability and large surface-to-volume ratio make them attractive as supports for metal catalysts and energy storage and conversion materials. Active metal and metal oxide nanoparticles can be impregnated into cavities or attached to the external walls of CNTs. The inertness of CNT walls requires their pretreatment with harsh oxidants to generate functional groups, or their modification with surfactants to allow deposition on their sidewalls. The strategies are effective, but can change the $p$-electron structure and thus the CNT properties. New approaches have included physical evaporation, electrodeless deposition, electrodeposition, and atomic layer deposition. These methods usually involve complicated process control, multiple step activation procedures, harsh conditions such as high temperatures or arc evaporation, and time-consuming treatment of the CNTs.

Wai's group [14] demonstrated that functionalized multi-walled carbon nanotubes (MWCNTs) could be homogeneously decorated with metal nanoparticles (Pd, $\mathrm{Rh}$ and $\mathrm{Ru}$ ), through the hydrogen reduction of organometallic precursors in $\mathrm{ScCO}_{2}$. The Pd-MWCNT composite exhibited high catalytic activity for the hydrogenation of olefins in $\mathrm{CO}_{2}$, and high electrocatalytic activity for oxygen reduction in fuel cells. Han' group $[17,19,20]$ demonstrated that $\mathrm{scCO}_{2}$-expanded ethanol could disperse hydrous metal nitrates within and on CNTs, forming a uniform oxide coating on the CNTs via the in situ decomposition of precursors. Multi-functional composites including $\mathrm{Al}_{2} \mathrm{O}_{3} / \mathrm{CNTs}$ [17], $\mathrm{CeO}_{2} / \mathrm{CNTs}$ [20] and $\mathrm{ZrO}_{2} / \mathrm{CNTs}$ [19] have been prepared in $\mathrm{scCO}_{2}$-expanded ethanol. 


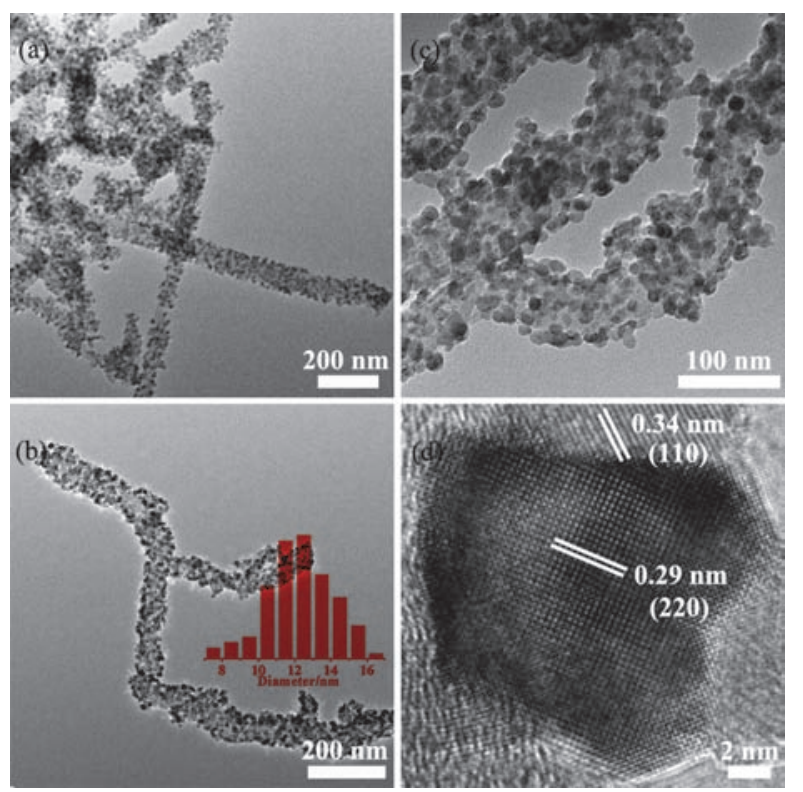

Fig. 4. (a-c) TEM and (d) HRTEM images of the p-CNTs@ $\mathrm{CoFe}_{2} \mathrm{O}_{4}$ composite [24].

We recently reported functionalized porous CNTs (p-CNTs) as supports and deposited electroactive metal oxide materials, with the assistance of $\mathrm{scCO}_{2}$-expanded ethanol. Porous CNTs were readily coated with uniform nanoparticle layers by controlling the reaction parameters. This is not easily achieved in pure ethanol. The resulting $\mathrm{Co}_{3} \mathrm{O}_{4} / \mathrm{p}$-CNT composite exhibited good performance as a LIB anode material. It retained a reversible capacity of $776 \mathrm{mAh} / \mathrm{g}$ with a Coulombic efficiency of $99.1 \%$ after 100 cycles. It exhibited a rate performance of 600 $\mathrm{mAh} / \mathrm{g}$ at a current density of $1 \mathrm{~A} / \mathrm{g}$ [23]. Bimetallic composites such as nanosized $\mathrm{CoFe}_{2} \mathrm{O}_{4}$ were also uniformly coated on the surface of p-CNTs without aggregation. The average diameter of the $\mathrm{CoFe}_{2} \mathrm{O}_{4}$ particles was $12 \mathrm{~nm}$, as shown in Fig. 4 [24]. Nanoparticles tend to agglomerate, because of the driving force to reduce their surface energy, yet agglomeration of $\mathrm{CoFe}_{2} \mathrm{O}_{4}$ was suppressed in this study. $\mathrm{scCO}_{2}$-expanded ethanol was an important factor in controlling the morphology of the nanoparticles on the substrate. p-CNTs@CoFe $\mathrm{O}_{4}$ exhibited excellent

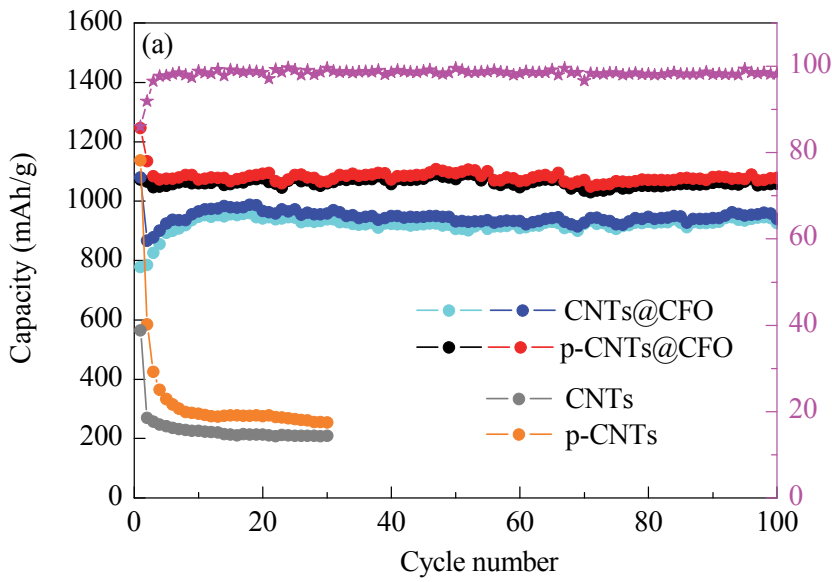

lithium storage properties in terms of cycling performance (1077 mAh/g after 100 cycles) and rate capability (694 mAh/g at $3 \mathrm{~A} / \mathrm{g}$ ), as shown in Fig. 5 [24].

\subsection{Two-dimensional graphene-based composites}

Graphene nanosheets (GNSs) exhibit high electronic conductivity, favorable mechanical properties, and high surface area (theoretical maximum of $2630 \mathrm{~m}^{2} / \mathrm{g}$ ). GNSs are attractive substrates for immobilizing functional materials for energy storage devices [32]. This application requires the mass production of graphene or their composites with controlled composition and microstructure. Metal oxide/GNS composites have been synthesized by coprecipitation [33], hydrothermal/solvothermal synthesis [34,35], and thermal decomposition [36,37]. The resulting composites usually have no specific dimensionality with respect to the metal oxides, or are not well dispersed on the support. This results in their loss from the support, and therefore loss of function. Free particles tend to form in solution during coprecipitation, because of the instant, local, high supersaturation of precipitating agents such as $\mathrm{NaOH}$. Nanosized transition metal oxides such as $\mathrm{NiO} / \mathrm{GNS}$ [32,38], $\mathrm{Co}_{3} \mathrm{O}_{4} / \mathrm{GNS}$ [39,40], $\mathrm{Mn}_{3} \mathrm{O}_{4} / \mathrm{GNS}$ [41], $\mathrm{Fe}_{3} \mathrm{O}_{4} / \mathrm{GNS}$ $[26,42,43], \mathrm{Fe}_{2} \mathrm{O}_{3} / \mathrm{GNS}[44]$, and $\mathrm{CuO} / \mathrm{GNS}[45,46]$ have all exhibited lithium storage capability. These nanomaterials agglomerate easily, because of their small size, large surface area, and high surface activity, which are detrimental to lithium storage. Agglomeration leads to an inhomogeneous dispersion of the active nanoparticles, and the electroactive materials cannot fully contact the electrolyte, which decreases the lithium storage performance.

We reported that nanosized $\mathrm{Fe}_{3} \mathrm{O}_{4}$ particles could be uniformly decorated on graphene surfaces without aggregation in $\mathrm{scCO}_{2}$-expanded ethanol, as shown in Fig. 6 [26]. The formation of dissociative particles in solution could also be avoided. Most $\mathrm{Fe}_{3} \mathrm{O}_{4}$ particles aggregated into large units in the absence of $\mathrm{scCO}_{2}$, with few particles loaded onto the graphene oxide. The control experiments indicated the importance of $\mathrm{scCO}_{2}$ in forming nanocomposites. When used as a LIB anode material, $\mathrm{Fe}_{3} \mathrm{O}_{4} / \mathrm{GNSs}$ containing $20 \% \mathrm{Fe}_{3} \mathrm{O}_{4}$ exhibited a charge capacity

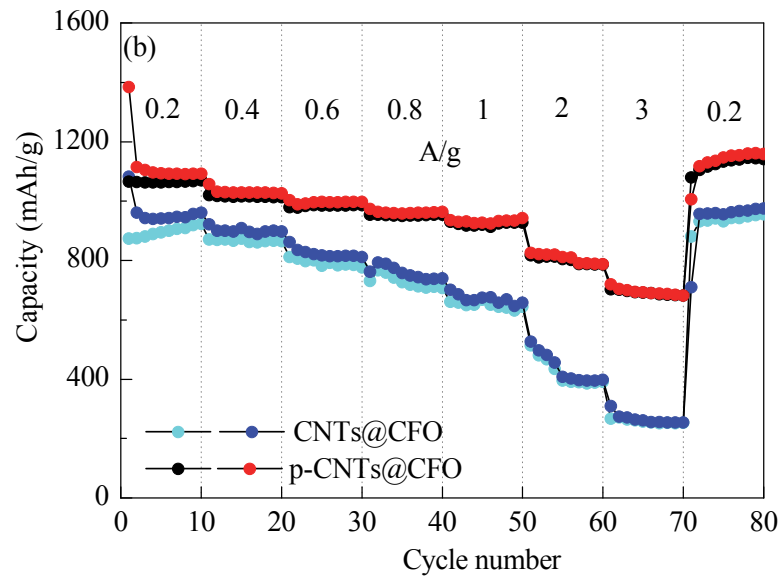

Fig. 5. (a) Cycle stability at $0.1 \mathrm{~A} / \mathrm{g}$ and Coulombic efficiency of p-CNTs@ $\mathrm{CoFe}_{2} \mathrm{O}_{4}$, and (b) rate performance [24]. 


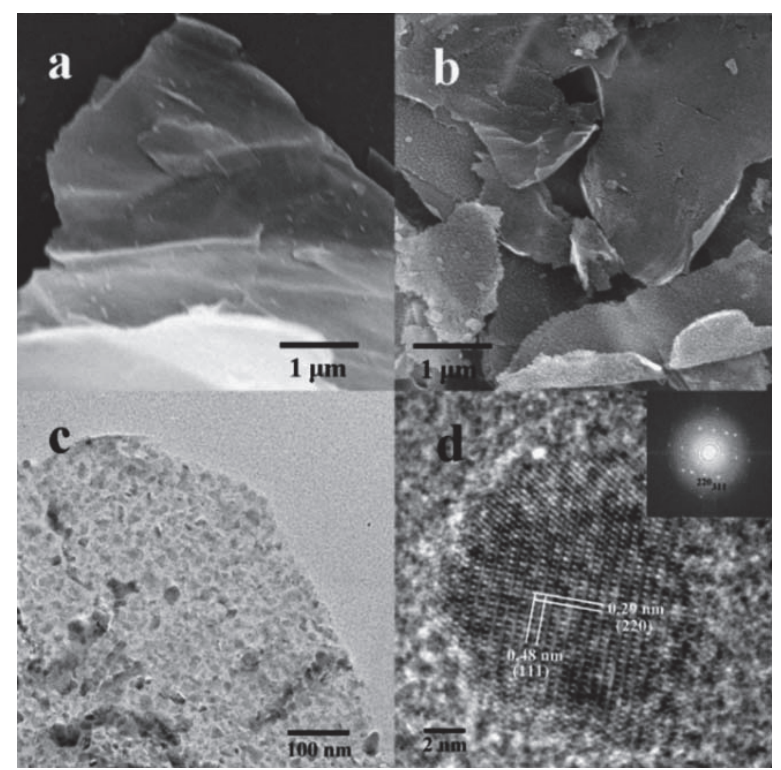

Fig. 6. SEM images of (a) Fe-salt@GO-CE-20 and (b) $\mathrm{Fe}_{3} \mathrm{O}_{4} @ G N-C E-20$. (c) TEM image of $\mathrm{Fe}_{3} \mathrm{O}_{4} @ G N-C E-20$. (d) HRTEM image of $\mathrm{Fe}_{3} \mathrm{O}_{4} @ G N-C E-20$. Reproduced from Ref. [26] with permission from the Royal Society of Chemistry.

of $826 \mathrm{mAh} / \mathrm{g}$ after the $100^{\text {th }}$ cycle. At a current density of 5 $\mathrm{A} / \mathrm{g}$, the composite delivered a capacity of $460 \mathrm{mAh} / \mathrm{g}$, which was higher than that of a sample synthesized in pure ethanol [26].

\subsection{Three-dimensional hierarchical porous carbon-based composites}

3D hierarchical porous carbons (3DHPCs) with well-defined macropores and interconnected meso- and micro-pores have also attracted much recent attention. Hierarchical porous architectures can exploit the structural advantages of macropores (improved mass transport) and micro-/mesopores (high surface area). Their high surface area, chemical inertness, and thermal stability make such porous carbons attractive as adsorbents $[47,48]$, catalyst supports [49-51], electrodes for batteries [52-54], double-layer capacitors [55,56], and host sites for hydrogen storage [57]. Yildirim's group [48] reported a 3DHPC with a surface area of $2734 \mathrm{~m}^{2} / \mathrm{g}$ and total pore volume of $5.53 \mathrm{~cm}^{3} / \mathrm{g}$, by tailored carbonization of a metal-organic framework. The 3DHPC exhibited a $\mathrm{CO}_{2}$ adsorption capability of $>27 \mathrm{mmol} / \mathrm{g}$ at $3 \mathrm{MPa}$ and $27^{\circ} \mathrm{C}$. This is among the highest reported values for porous carbons. Stein and co-workers [54] reported uniform coatings of electrochemically active $\mathrm{SnO}_{2}$ on 3D ordered macroporous (3DOM) carbon, via an aqueous salt-imbibition process. These composites exhibited good electrochemical performance in LIBs. The 3DOM carbon decreased the solid-state diffusion length for $\mathrm{Li}^{+}$by a few tens of nanometers, provided numerous active sites for charge-transfer reactions, and gave reasonable electrical conductivity within the 3DHPC matrix.

$\mathrm{ScCO}_{2}$ can dissolve solutes like a liquid, but exhibits low viscosity, high diffusivity, and zero surface tension like a gas. These properties make $\mathrm{scCO}_{2}$ an attractive medium for delivering reactants to areas with high aspect ratios, complicated surfaces, and poorly wettable substrates. This enables deposition to be controlled quantitatively and uniformly. The loading amount can be controlled by varying the precursor concentration. We reported a series of carbon-based composites of metal oxides and 3DHPC, including $\mathrm{Fe}_{3} \mathrm{O}_{4} / 3 \mathrm{DHPC}$, NiO/3DHPC, $\mathrm{Co}_{3} \mathrm{O}_{4} / 3 \mathrm{DHPC}$, and $\mathrm{NiCo}_{2} \mathrm{O}_{4} / 3$ DHPC [28,29]. $\mathrm{Fe}_{3} \mathrm{O}_{4} / 3 \mathrm{DHPC}$ contained small uniform $\mathrm{Fe}_{3} \mathrm{O}_{4}$ nanoparticles distributed on a 3DHPC support. It was prepared by deposition assisted with a $\mathrm{scCO}_{2}$-expanded ethanol solution, in which the support could be used without pretreatment or surfactants. The loading or thickness of the $\mathrm{Fe}_{3} \mathrm{O}_{4}$ layer could be controlled by changing the concentration of the ferric nitrate precursor. $\mathrm{Fe}_{3} \mathrm{O}_{4}$ nanoparticles of 11-15 nm in diameter were coated on the surface of the interconnected porous 3DHPC network, and no free $\mathrm{Fe}_{3} \mathrm{O}_{4}$ particles were formed, even at high loading (86\%), as shown in Fig. 7 [28]. In contrast, the composite of $\mathrm{Fe}_{3} \mathrm{O}_{4}$ and 3DHPC synthesized by the conventional solvothermal method resulted in many free $\mathrm{Fe}_{3} \mathrm{O}_{4}$ particles. These composites exhibited good performance as LIB anode materials. $\mathrm{Fe}_{3} \mathrm{O}_{4} / 3 \mathrm{DHPC}$ containing $79 \% \mathrm{Fe}_{3} \mathrm{O}_{4}$ delivered a reversible capacity of $1462 \mathrm{mAh} / \mathrm{g}$ after 100 cycles at a current density of $100 \mathrm{~mA} / \mathrm{g}$, and maintained a rate performance of 728,507 and $239 \mathrm{mAh} / \mathrm{g}$ at 1, 2, and $5 \mathrm{~A} / \mathrm{g}$, respectively. It exhibited excellent long-term cycling performance at current densities of 1 and $2 \mathrm{~A} / \mathrm{g}$, as shown in Fig. 8 [28]. We also prepared composites of metal oxides $\left(\mathrm{NiO}, \mathrm{Co}_{3} \mathrm{O}_{4}\right)$ and mixed metal oxides $\left(\mathrm{NiCO}_{2} \mathrm{O}_{4}\right)$ with 3DHPC. Ni-
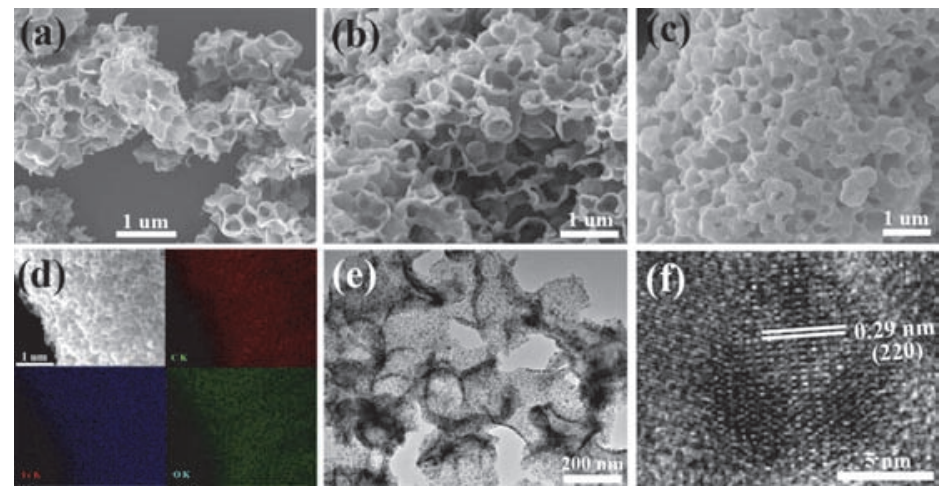

Fig. 7. SEM images of (a) $\mathrm{Fe}_{3} \mathrm{O}_{4} / 3$ DHPC-65, (b) $\mathrm{Fe}_{3} \mathrm{O}_{4} / 3 \mathrm{DHPC}-79$, and (c) $\mathrm{Fe}_{3} \mathrm{O}_{4} / 3$ DHPC-86. (d-f) Elemental mapping, TEM, and HRTEM images of $\mathrm{Fe}_{3} \mathrm{O}_{4} / 3$ DHPC-79, respectively [28]. 

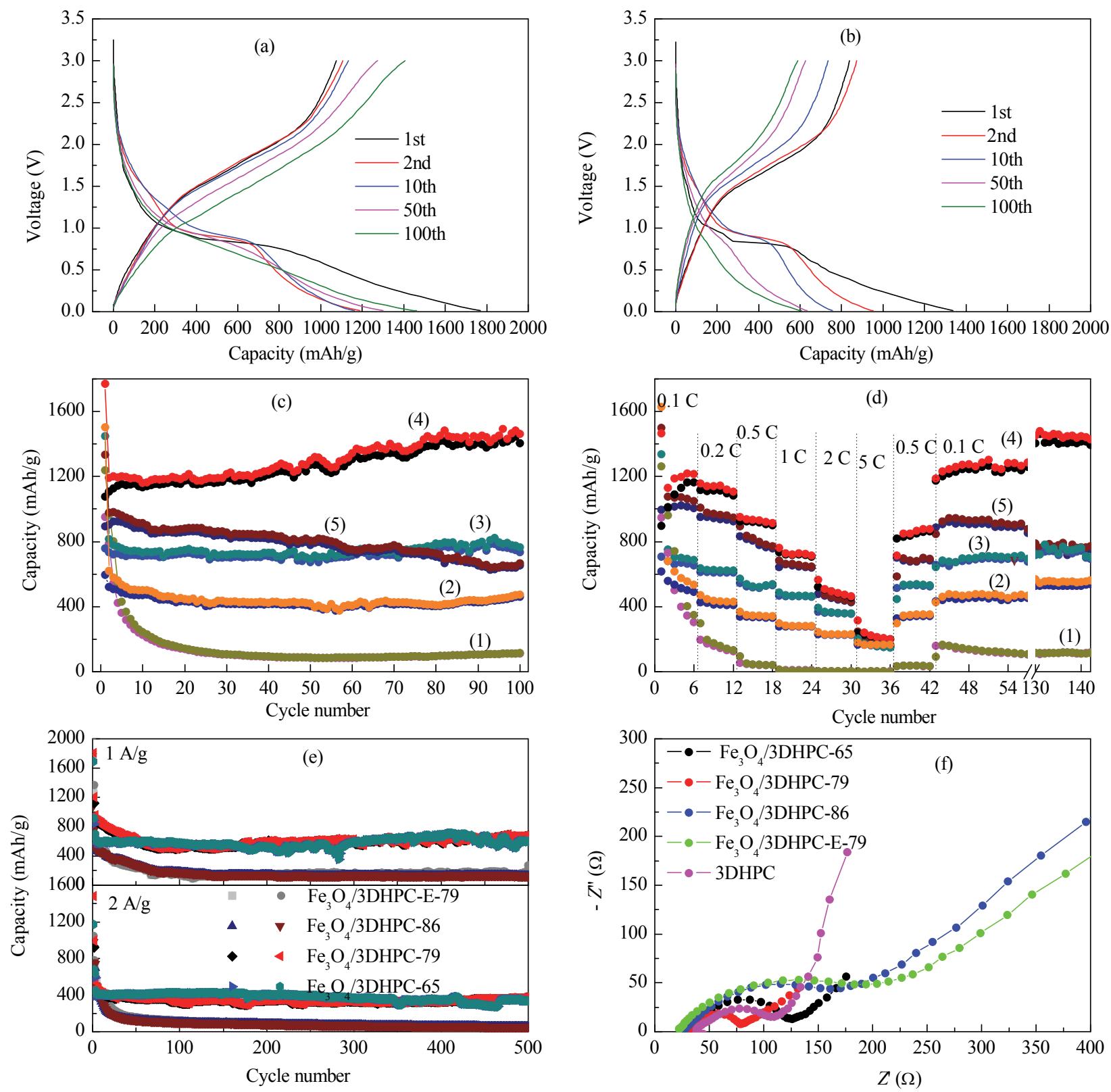

Fig. 8. Charge/discharge voltage profiles of (a) $\mathrm{Fe}_{3} \mathrm{O}_{4} / 3 \mathrm{DHPC}-79$ and (b) $\mathrm{Fe}_{3} \mathrm{O}_{4} / 3 \mathrm{DHPC}-\mathrm{E}-79$ at $100 \mathrm{~mA} / \mathrm{g}$. (c) Cycling and (d) rate performances of (1) commercial $\mathrm{Fe}_{3} \mathrm{O}_{4}$, (2) bare 3DHPC, (3) $\mathrm{Fe}_{3} \mathrm{O}_{4} / 3 \mathrm{DHPC}-65$, (4) $\mathrm{Fe}_{3} \mathrm{O}_{4} / 3$ DHPC-79, and (5) $\mathrm{Fe}_{3} \mathrm{O}_{4} / 3 \mathrm{DHPC}-86$. (e) Cycling tests of the $\mathrm{Fe}_{3} \mathrm{O}_{4} / 3 \mathrm{DHPC}$ electrodes. (f) Nyquist plots of electrodes after 100 cycles at $100 \mathrm{~mA} / \mathrm{g}$ at $100 \mathrm{kHz}-0.1 \mathrm{~Hz}$ [28].

$\mathrm{Co}_{2} \mathrm{O}_{4} / 3 \mathrm{DHPC}$ exhibited good electronic conductivity and electrochemical activity with a reversible capacity of $660 \mathrm{mAh} / \mathrm{g}$, and a capacity retention of $92.3 \%$ for up to 500 cycles at a current density of $1 \mathrm{~A} / \mathrm{g}$. The excellent electrochemical performance was attributed to the uniform dispersion of $\mathrm{NiCo}_{2} \mathrm{O}_{4}$ nanoparticles on the 3DHPC, as a result of the $\mathrm{scCO}_{2}$-expanded ethanol medium.

\section{Conclusions}

$\mathrm{scCO}_{2}$-expanded ethanol deposition is an efficient, versatile and green strategy for coating metal and metal oxide on car- bon-based supports. It avoids the formation of free metal and metal oxide particles, and gives good individual particle dispersion. The composition, thickness, uniformity, and structure of the noble and non-noble metal and metal oxide shells can be precisely controlled. This strategy allows nanostructured materials to be prepared more easily and precisely than by conventional deposition. The resulting composites exhibit good catalytic activity and electrochemical performance in LIBs. It remains difficult to achieve large-scale production of the composites, because of the limited solubility of metal nitrates in the supercritical fluid and $\mathrm{CO}_{2}$-expanded ethanol. Reaction vessels required a good seal, as reaction occurs at high pressure and 


\section{Graphical Abstract}

Chin. J. Catal., 2016, 37: 218-226 doi: 10.1016/S1872-2067(15)61024-5

Carbon dioxide-expanded ethanol-assisted synthesis of carbon-based metal composites and their catalytic and electrochemical performance in lithium-ion batteries

Lingyan Wang, Linhai Zhuo*, Fengyu Zhao* Qufu Normal University; Taishan University; Changchun Institute of Applied Chemistry, Chinese Academy of Sciences

The recent advances in supercritical $\mathrm{CO}_{2}$-expanded ethanol assisted deposition of metal (oxide) nanoparticles on different dimensional carbon materials are reviewed. The catalytic and electrochemical performances of the prepared functional composites are introduced.

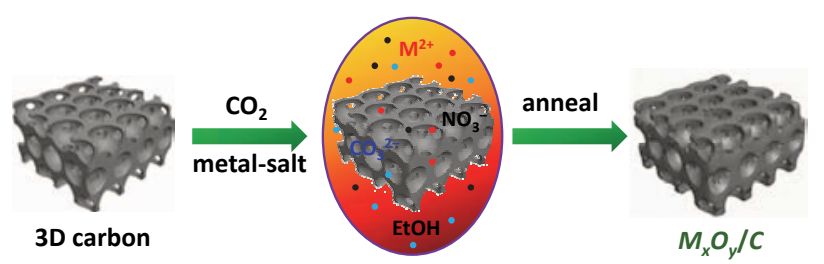

temperature. It remains necessary to explore suitable cosolvents for forming $\mathrm{CO}_{2}$-expanded media at lower pressure, and to improve the solubility of the metal precursors.

\section{References}

[1] Y. D. Yin, R. M. Rioux, C. K. Erdonmez, S. Hughes, G. A. Somorjai, A. P. Alivisatos, Science, 2004, 304, 711-714.

[2] P. M. Arnal, M. Comotti, F. Schüth, Angew. Chem. Int. Ed., 2006, 45, 8224-8227.

[3] J. M. Yan, X. B. Zhang, T. Akita, M. Haruta, Q. Xu, J. Am. Chem. Soc., 2010, 132, 5326-5327.

[4] S. Yang, W. B. Yue, J. Zhu, Y. Ren, X. J. Yang, Adv. Funct. Mater., 2013, 23, 3570-3576.

[5] C. N. He, S. Wu, N. Q. Zhao, C. S. Shi, E. Z. Liu, J. J. Li, ACS Nano, 2013, 7, 4459-4469.

[6] Z. S. Wu, W. C. Ren, L. Wen, L. B. Gao, J. P. Zhao, Z. P. Chen, G. M. Zhou, F. Li, H. M. Cheng, ACS Nano, 2010, 4, 3187-3194.

[7] Y. J. Gao, D. Ma, C. L. Wang, J. Guan, X. H. Bao, Chem. Commun., 2011, 47, 2432-2434.

[8] X. M. Chen, G. H. Wu, J. M. Chen, X. Chen, Z. X. Xie, X. R. Wang, J. Am. Chem. Soc., 2011, 133, 3693-3695.

[9] Z. Y. Sun, Y. F. Zhao, Y. Xie, R. T. Tao, H. Y. Zhang, C. L. Huang, Z. M. Liu, Green Chem., 2010, 12, 1007-1011.

[10] Y. F. Zhao, H. Y. Zhang, C. L. Huang, S. Chen, Z. M. Liu, J. Colloid Interf. Sci., 2012, 374, 83-88.

[11] N. Li, M. H. Cao, Q. Y. Wu, C. W. Hu, CrystEngComm, 2012, 14 428-434.

[12] P. Balaya, Energy Environ. Sci., 2008, 1, 645-654.

[13] E. Kang, Y. S. Jung, A. S. Cavanagh, G. H. Kim, S. M. George, A. C. Dillon, J. K. Kim, J. Lee, Adv. Funct. Mater., 2011, 21, 2430-2438.

[14] X. R. Ye, Y. H. Lin, C. M. Wang, M. H. Engelhard, Y. Wang, C. M. Wai, J. Mater. Chem., 2004, 14, 908-913.

[15] L. Fu, Z. M. Liu, Y. Q. Liu, B. X. Han, P. A. Hu, L. C. Cao, D. B. Zhu, $A d v$ Mater., 2005, 17, 217-221.

[16] L. Fu, Z. M. Liu, Y. Q. Liu, B. X. Han, J. Q. Wang, P. A. Hu, L. C. Cao, D. B. Zhu, Adv. Mater., 2004, 16, 350-352.

[17] L. Fu, Y. Q. Liu, Z. M. Liu, B. X. Han, L. C. Cao, D. C. Wei, G. Yu, D. B. Zhu, Adv. Mater, 2006, 18, 181-185.

[18] Z. Y. Sun, H. Q. Yuan, Z. M. Liu, B. X. Han, X. R. Zhang, Adv. Mater., 2005, 17, 2993-2997.

[19] Z. Y. Sun, X. R. Zhang, N. Na, Z. M. Liu, B. X. Han, G. M. An, J. Phys. Chem. B, 2006, 110, 13410-13414.

[20] Z. Y. Sun, X. R. Zhang, B. X. Han, Y. Y. Wu, G. M. An, Z. M. Liu, S. D.
Miao, Z. J. Miao, Carbon, 2007, 45, 2589-2596.

[21] J. Ming, H. Y. Cheng, Y. C. Yu, Y. Q. Wu, F. Y. Zhao, J. Mater. Chem., 2011, 21, 6654-6659.

[22] Q. Wang, H. Y. Cheng, R. X. Liu, J. M. Hao, Y. C. Yu, F. Y. Zhao, Green Chem., 2010, 12, 1417-1422.

[23] L. H. Zhuo, Y. Q. Wu, J. Ming, L. Y. Wang, Y. C. Yu, X. B. Zhang, F. Y. Zhao, J. Mater. Chem. A, 2013, 1, 1141-1147.

[24] L. Y. Wang, L. H. Zhuo, H. Y. Cheng, C. Zhang, F. Y. Zhao, J. Power Sources, 2015, 283, 289-299.

[25] L. H. Zhuo, Y. Q. Wu, W. Zhou, L. Y. Wang, Y. C. Yu, X. B. Zhang, F. Y. Zhao, ACS Appl. Mater. Interf., 2013, 5, 7065-7071.

[26] L. H. Zhuo, Y. Q. Wu, L. Y. Wang, J. Ming, Y. C. Yu, X. B. Zhang, F. Y. Zhao, J. Mater. Chem. A, 2013, 1, 3954-3960.

[27] L. Y. Wang, L. H. Zhuo, C. Zhang, F. Y. Zhao, J. Power Sources, 2015, $275,650-659$.

[28] L. Y. Wang, L. H. Zhuo, C. Zhang, F. Y. Zhao, Chem. Eur. J., 2014, 20, 4308-4315.

[29] L. Y. Wang, L. H. Zhuo, C. Zhang, F. Y. Zhao, ACS Appl. Mater. Interf., 2014, 6, 10813-10820.

[30] C. Erkey, J. Supercrit. Fluids, 2009, 47, 517-522.

[31] J. Ming, C. Y. Wu, H. Y. Cheng, Y. C. Yu, F. Y. Zhao, J. Supercrit. Fluids, 2011, 57, 137-142.

[32] V. Chabot, D. Higgins, A. P. Yu, X. C. Xiao, Z. W. Chen, J. J. Zhang, Energy Environ. Sci., 2014, 7, 1564-1596.

[33] W. Y. Bian, Z. R. Yang, P. Strasser, R. Z. Yang, J. Power Sources, 2014, 250, 196-203.

[34] D. N. Wang, J. L. Yang, X. F. Li, D. S. Geng, R. Y. Li, M. Cai, T. K. Sham, X. L. Sun, Energy Environ. Sci., 2013, 6, 2900-2906.

[35] W. Wei, S. B. Yang, H. X. Zhou, I. Lieberwirth, X. L. Feng, K. Muellen, Adv. Mater., 2013, 25, 2909-2914.

[36] L. W. Yin, Z. W. Zhang, Z. Q. Li, F. B. Hao, Q. Li, C. X. Wang, R. H. Fan, Y. X. Qi, Adv. Funct. Mater., 2014, 24, 4176-4185.

[37] Y. H. Jin, S. D. Seo, H. W. Shim, K. S. Park, D. W. Kim, Nanotechnology, 2012, 23, 125402-125402.

[38] J. W. Xiao, G. L. Xu, S. G. Sun, S. H. Yang, Part. Part. Syst. Charact., 2013, 30, 893-904.

[39] H. Kim, D. H. Seo, S. W. Kim, J. Kim, K. Kang, Carbon, 2011, 49, 326-332.

[40] B. J. Li, H. Q. Cao, J. Shao, G. Q. Li, M. Z. Qu, G. Yin, Inorg. Chem., 2011, 50, 1628-1632.

[41] H. L. Wang, L. F. Cui, Y. Yang, H. S. Casalongue, J. T. Robinson, Y. Y. Liang, Y. Cui, H. J. Dai, J. Am. Chem. Soc., 2010, 132, 13978-13980.

[42] J. Su, M. H. Cao, L. Ren, C. W. Hu, J. Phys. Chem. C, 2011, 115, 14469-14477. 
[43] M. Sathish, T. Tomai, I. Honma, J. Power Sources, 2012, 217, 85-91.

[44] Y. Q. Zou, J. Kan, Y. Wang, J. Phys. Chem. C, 2011, 115, 20747-20753.

[45] L. Q. Lu, Y. Wang, J. Mater. Chem., 2011, 21, 17916-17921.

[46] B. Wang, X. L. Wu, C. Y. Shu, Y. G. Guo, C. R. Wang, J. Mater. Chem., 2010, 20, 10661-10664.

[47] L. Estevez, R. Dua, N. Bhandari, A. Ramanujapuram, P. Wang, E. P. Giannelis, Energy Environ. Sci., 2013, 6, 1785-1790.

[48] G. Srinivas, V. Krungleviciute, Z. X. Guo, T. Yildirim, Energy Environ. Sci., 2014, 7, 335-342.

[49] D. S. Yang, D. Bhattacharjya, S. Inamdar, J. Park, J. S. Yu, J. Am. Chem. Soc., 2012, 134, 16127-16130.

[50] Z. K. Sun, B. Sun, M. H. Qiao, J. Wei, Q. Yue, C. Wang, Y. H. Deng, S Kaliaguine, D. Y. Zhao, J. Am. Chem. Soc., 2012, 134, 17653-17660.
[51] T. B. Wu, P. Zhang, J. Ma, H. L. Fan, W. T. Wang, T. Jiang, B. X. Han, Chin. J. Catal., 2013, 34, 167-175.

[52] B. Zhang, M. Xiao, S. J. Wang, D. M. Han, S. Q. Song, G. H. Chen, Y. Z. Meng, ACS Appl. Mater. Interf., 2014, 6, 13174-13182.

[53] Y. S. Hu, P. Adelhelm, B. M. Smarsly, S. Hore, M. Antonietti, J. Maier, Adv. Funct. Mater., 2007, 17, 1873-1878.

[54] K. T. Lee, J. C. Lytle, N. S. Ergang, S. M. Oh, A. Stein, Adv. Funct. Mater., 2005, 15, 547-556.

[55] H. Yamada, H. Nakamura, F. Nakahara, I. Moriguchi, T. Kudo, J. Phys. Chem. C, 2007, 111, 227-233.

[56] W. Xing, S. Z. Qiao, R. G. Ding, F. Li, G. Q. Lu, Z. F. Yan, H. M. Cheng, Carbon, 2006, 44, 216-224.

[57] H. L. Wang, Q. M. Gao, J. Hu, J. Am. Chem. Soc., 2009, 131, 7016-7022.

\title{
二氧化碳膨胀乙醇体系中碳基金属复合物的合成及其催化和电化学性能
}

\author{
王凌燕 ${ }^{\mathrm{a}}$, 禚林海, , $^{*}$, 赵风玉 ${ }^{\mathrm{c}, \#}$ \\ ${ }^{\mathrm{a}}$ 曲阜师范大学化学与化工学院, 山东曲阜 273165

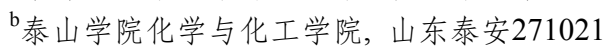 \\ c 中国科学院长春应用化学研究所, 电分析化学国家重点实验室, 绿色化学与过程实验室, 吉林长春130022
}

摘要: 与块体材料相比, 功能复合材料表现了更加优异的性能, 而且比其中任何单一组分的性能都好, 因此在催化、锂离子 电池等领域得以广泛研究. 通常情况下, 在复合材料的制备中金属或金属氧化物粒子要求能够以足够小的粒径在基底上 均匀分散, 并实现活性组分负载量的可控. 据报道, 很多方法可以将金属 (或氧化物) 活性组分引入到载体之中, 比如水热/ 溶剂热、水解、热分解、化学气相沉积等, 但这些方法均存在如下缺点. 第一, 为了获得满意的负载量和可控包覆, 碳基底 需要预氧化处理使其表面含有丰富的含氧官能团. 例如, 由于碳纳米管自身的相容性和加工性较差, 需要硝酸预氧化处理; 石墨烯也需要预处理为石墨烯氧化物然后再进行第二组分的负载. 但是, 剧烈的氧化处理条件不可避免地造成对碳 $s p^{2}$ 结 构和电子特性的破坏, 并且增加了繁杂的后续处理过程. 第二, 金属组分前驱体在基底上负载不完全, 易形成自由粒子聚 集在溶液中, 从而降低活性组分的有效利用. 第三, 传统方法中由于使用水、乙醇等表面张力大的极性溶剂, 导致粒子结晶 再生长, 形成的颗粒尺寸大, 对催化剂会降低活性表面积及催化效率; 对于电池材料会增加电极/电解液的接触面积, 增加 锂离子的扩散距离及电池充电过程的内部应力. 而且, 有机溶剂由于粘度大, 不利于金属纳米粒子在基底上的均匀分散及 合成过程的绿色化. 因此, 我们利用资源丰富, 廉价的二氧化碳作为绿色溶剂, 研究了二氧化碳膨胀的乙醇体系中金属 (氧 化物) 纳米粒子在碳基底上均匀负载的方法. 由于超临界二氧化碳具有独特的低粘度、“零”表面张力、高扩散能力、以及 物性参数随温度和压力可调等特点, 可以使金属 (氧化物) 前驱体不受液体毛细作用的限制在孔道中快速、均一地分散, 保 证孔结构稳定, 对多孔复合材料的加工和制备表现了巨大的优势. 同时, 超临界二氧化碳的抗溶剂能力也能够有效降低乙 醇和水引起的溶剂效应, 从而降低纳米粒子之间的聚集. 此外, 通过改变前驱体的浓度可以精确调控表面组分的负载量. 更重要的是, 碳基底可以直接利用制备碳基复合材料, 无需任何预处理及表面活性剂参与, 避免了前处理对基底的形貌和 电子特性的破坏.

本综述首先介绍了超临界二氧化碳膨胀乙醇体系的属性,讨论了碳基复合材料在该体系中的形成机理. 然后分别介绍 了零维碳球、一维碳纳米管、二维石墨烯、三维多孔碳材料作为基底形成的一系列金属 (氧化物) 复合材料, 及这些材料在 催化和锂离子电池领域中的应用. 最后, 对超临界二氧化碳沉积方法的应用进行了总结和展望.

关键词: 二氧化碳膨胀乙醇; 碳材料; 金属氧化物; 催化; 电化学

收稿日期: 2015-11-05. 接受日期: 2015-12-02. 出版日期: 2016-02-05.

*通讯联系人. 电话: (0538)6715156; 传真: (0538)6715599; 电子信箱: zhuoling77@163.com

\#通讯联系人. 电话: (0431)85262410; 传真: (0431)85262410; 电子信箱: zhaofy@ciac.ac.cn

基金来源：国家自然科学基金会与日本学术振兴会国际合作项目 (21311140166); 国家自然科学基金 (21273222); 山东省科技计 划项目 (2014GGX102020); 山东省高校科技计划项目 (J14LC08); 曲阜师范大学博士科研启动基金; 曲阜师范大学科技计划项目 (xkj201508).

本文的英文电子版由Elsevier出版社在ScienceDirect上出版(http://www.sciencedirect.com/science/journal/18722067). 